\title{
Surface treatment of implants: primary stability
}

\author{
Tratamento de superfície de implantes: frequência de ressonância
}

Nathalia Ferraz OLISCOVICZ ${ }^{1}$

Ronaldo José da SILVA ${ }^{1}$

César Penazzo LEPRI ${ }^{2}$

Élcio MARCANTONIO JUNIOR'

Andréa Cândido dos REIS ${ }^{1}$

\section{ABSTRACT}

\section{Objective}

The aim of this study was to analyze the primary stability of dental implants with and without surface treatment, by means of resonance frequency, using different materials as substitutes for human bone substrates for insertion.

\section{Methods}

Sixteen external hexagon, cylindrical Conexão ${ }^{\circledR}$ titanium implants were used, $11.5 \mathrm{~mm}$ long by $3.75 \mathrm{~mm}$ wide, as follows: 8 Master Porous (MP), with surface treatment and 8 Master Screw (MS) machined. The implant placement was performed on the following substrates: pork rib bone, wood, artificial bone polyurethane National ${ }^{\circledR}\left(40,20,15\right.$ PCF) and Synbone ${ }^{\circledR}$. Primary stability was assessed via resonance frequency using an Osstell Mentor ${ }^{\mathrm{TM}}$ device. Data were analyzed statistically using ANOVA and Tukey's test, with a significance level of 5\%.

\section{Results}

It was found that although MP and MS have a higher value on all substrates, these were not statistically different between groups ( $p>0.05$ ), except for polyurethane National ${ }^{\circledR} 20$ PCF. When inserted into the wood substrate and polyurethane National ${ }^{\circledR} 40$ PCF, MP and MS had higher values. MP, when inserted into the pig bone, was also statistically equal to these interactions.

\section{Conclusion}

Despite the continuous development of innovations in the characteristics of implant surfaces to assist with the performance of osseointegrated implants, and the fact that our study has found that the surface treatment had no impact on the primary stability checked using ressonance frequency, there is still very little scientific understanding of these effects.

Indexing terms: Bone density. Dental implantation. Frequency.

\section{RESUMO}

\section{Objetivo}

Analisar a estabilidade primária de implantes odontológicos com tratamento e sem tratamento de superfície, por meio da frequência de ressonância, utilizando diferentes materiais como substratos substitutos do osso humano para sua inserção.

\section{Métodos}

Foram utilizados 16 implantes de titânio Conexão ${ }^{\circledR}$, cilíndricos, hexágono externo, com 11,5 mm de comprimento e 3,75 mm de largura, sendo: 8 Master Porous, com tratamento de superfície; e 8 Master Screw, usinados. A instalação de implantes foi realizada nos seguintes substratos: osso de costela suína, madeira, osso artificial de poliuretana da marca Nacional ${ }^{\circledR}\left(40,20\right.$ e 15 PCF) e da marca Synbone ${ }^{\circledR}$. Foi avaliada a estabilidade primária através da frequência de ressonância utilizando o aparelho Osstell TM Mentor. Os dados obtidos foram submetidos a tratamento estatístico ANOVA e Teste de Tukey, com nível de significância a $5 \%$.

\section{Resultados}

Foi constatado que, apesar de Master Porous apresentar maior valor que Master Screw em todos os substratos, estes não apresentaram diferença estatística entre si (p>0,05), com exceção da poliuretana Nacional ${ }^{\circledR}$ de 20 PCF. Quando inseridos no substrato madeira e na poliuretana Nacional ${ }^{\circledR} 40$ PCF, Master Porous e Master Screw tiveram maiores valores. Master Porous, quando inserido no osso suíno também foram iguais estatisticamente a estas interações.

\section{Conclusão}

Apesar de inovações nas características das superfícies de implantes serem desenvolvidas constantemente para contribuir no desempenho de implantes osseointegrados, e nosso estudo encontrar que não houve influência do tratamento de superfície na estabilidade primária aferida por frequência de ressonância; ainda há pouco conhecimento científico sobre esses efeitos.

Termos de indexação: Densidade óssea. Implantação dentária. Frequencia.

\footnotetext{
${ }^{1}$ Universidade de São Paulo, Faculdade de Odontologia, Departamento de Materiais Dentários e Prótese. Av. do Café, s/n., 14040-904, Ribeirão Preto, SP, Brasil. Correspondência para / Correspondence to: AC REIS.E-mail: <andreare73@yahoo.com.br>.

${ }^{2}$ Universidade Estadual Paulista Júlio de Mesquita Filho, Faculdade de Odontologia, Departamento de Diagnóstico e Cirurgia. Araraquara, SP, Brasil.
} 


\section{INTRODUCTION}

The use of endosseous implants in oral rehabilitation has witnessed a significant increase in recent years due to studies showing high success rates ${ }^{1-5}$ and scientific and industrial developments that have broadened the application of these implants. To achieve osseointegration, it is crucial that during surgery the implant is stabilized in the receiving bone site ${ }^{6}$, attaining primary stability $2,6-10$. This initial fixation depends on surgical technique, implant design and on patient-related factors such as bone density ${ }^{1,10-11}$

To determine the occurrence of primary implant stability, many non-invasive techniques are used, such as tactile sensitivity based on subjective perception ${ }^{1,7-9}$. The Periotest is an instrument that assesses tooth or implant mobility ${ }^{8}$, however its applicability for this purpose is poor due to its low senitivity2,4,8. Insertion torque is equal to the implant's final seating torque in the receiving bone site ${ }^{6}$, but this can only be assessed per operandum ${ }^{2,8}$.

Resonance frequency analysis can be used to to determine primary stability at any moment during the bone healing process, after the implant is inserted ${ }^{2-3,8,12}$. This consists of a clinical assessment of the implant's vibratory oscillations by way of a transducer connected to it. $^{3-4,6,8}$. The value, given by the implant stability quotient (ISQ), is influenced by the bone adjacent to the implant and the rigidity of the bone-implant interface $2-4,9,12-13$. Thus researchers have been concerned with comparing resonance frequency with bone density ${ }^{14}$, along with other methods for analyzing primary stability, in order to properly observe correlation ${ }^{6}$, as previous works have stated that the surgeon's ability to predict primary stability by subjective analysis is not always effective, mainly at low values of resonance frequency and insertion torque. Therefore, more objective, systematic measurements should be encouraged, mainly in cases where immediate load protocol is the aim? ${ }^{7}$.

However, many studies that analyze resonance frequency are performed on the bones of cadavers or in clinical situations where variability exists between samples or individuals ${ }^{2}$. In light of these difficulties, mainly in conducting research that assesses the true influence of an implant's design and surface treatment on its primary stability, a homogeneous substrate should be used to perform these studies so that other variables do not influence results ${ }^{8}$. Thus, the literature proposes a number of materials with different, though relatively homogeneous densities, that may serve as substrates and bone substitutes for the placement of implants ${ }^{15}$. However, there is still a need, within the scientific community, to find a substrate that is similar to bone tissue and to examine the influence on this substrate of implant surface treatment, immediately after insertion.

Thus, the aims of this study were to assess the primary stability, through resonance frequency analysis, of implants both with and without surface treatment, using different materials as human bone substitute substrates for their insertion, as well as to correlate these results with the material's specific density.

\section{METHODS}

\section{Experiments}

The placement of implants was performed with substrates obtained from the following materials: pig rib bone, wood and artificial polyurethane bone manufactured by Nacional ${ }^{\circledR}$ (Nacional Ossos, Jaú, São Paulo, Brazil) and Synbone ${ }^{\circledR}$ (Synbone AG, Malans, Switzerland). For the analysis of primary stability, the measurement of the resonance frequency was performed.

\section{Substrates for implant placement}

Pig ribs were chosen in accordance with previously conducted studies in dentistry, in which they were used as substitutes for human mandible and maxilla bones due to their similarity with cortical and trabecular bones ${ }^{13}$. All the ribs were obtained from the same animal and were cut into 20 $\mathrm{mm}$ segments after removal of the soft tissue. Sixteen bone segments were chosen that had approximately the same thickness as cortical and cancellous bones. The bones were stored in a freezer at a temperature of $-21 \pm 5^{\circ} \mathrm{C}$ in order to maintain their physical properties and, prior to the surgical procedures and implant stability measurements, were thawed at ambient temperature for 48 hours so as to attain the actual conditions of a living bone's biomechanical properties ${ }^{15-16}$.

Pine wood from the Araucaria Angustifolia species was used, chosen due to its similarity to human bone with regard to the perceived sensation when drilling and fitting implants ${ }^{17}$, most likely because its basic density ${ }^{18}$ ranges from 0.42 to $0.48 \mathrm{~g} / \mathrm{cm}^{3}$, similar to the averages of mandible and maxilla bones ${ }^{19}$. Furthermore, it possesses anisotropy, which means that it is a material that does not have the same properties with regard to the three main directions of application of stress - longitudinal, tangential and radial20; a property also present in bone. Pieces of wood with a diameter of $30 \mathrm{~mm}$ were sectioned into $13 \mathrm{~mm}$ high test specimens 
and shaped into cylinders in the precision workshop at the Faculty of Medicine in Ribeirão Preto.

The use of polyurethane human bone substitutes, as standard materials for implant placement in the mechanical testing of orthopedic implants (ASTM 1839$08)^{21}$, was suggested by Cristofolini \& Viceconti ${ }^{15,22}$, who concluded that synthetic polyurethane bones have a similar flexion to that of bones of cadavers and can therefore constitute a reproducible protocol for the assessment of implant stability. Nacional ${ }^{\circledR}$ polyurethane blocks were supplied by the manufacturer at three different levels of density: 40, 20 and 15 PCF or $0.64 \mathrm{~g} / \mathrm{cm}^{3}, 0.32 \mathrm{~g} / \mathrm{cm}^{3}$ and $0.24 \mathrm{~g} / \mathrm{cm}^{3}$, respectively, with the following dimensions: height of $4.2 \mathrm{~cm}$, width of $17.8 \mathrm{~cm}$ and length of $6.5 \mathrm{~cm}$. The Synbone ${ }^{\circledR}$ polyurethane test specimens were obtained by cutting the femoral head of the bone so that all samples would have approximately the same thickness of cortical and trabecular bone. The reason for using the femoral head as an experimental model is due to the fact that the thickness of the femoral cortical bone is similar to that of the maxilla and mandible. Besides having a thin layer of cortical bone, this region consists of rich trabecular bone, which enables the impact of this bone on primary stability to be studied'.

\section{Implants}

A total of 16 Conexão ${ }^{\circledR}$ (Conexão, Jaú, Brazil) cylindrical, titanium external hex screws were used in this study, with a length of $11.5 \mathrm{~mm}$ and width of $3.75 \mathrm{~mm}$, consisting of the following: 8 Master Porous implants, with Porous surface treatment and 8 Master Screw implants, without surface treatment. The same implants were used in all types of substrate.

\section{Study protocol}

The implants were inserted in each substrate by a single operator, with drilling beginning at $7 \mathrm{~mm}$ from the mark of the adjacent implant, with the aid of a Dentscler ${ }^{\circledR}$ Omega MC 101 surgical electric motor adjusted to a torque of $45 \mathrm{~N}$, at a speed of $1861 \mathrm{rpm}$ and using a 16:1 contra-angle attachment (Dentscler Indústria de Aparelhos Odontológicos Ltda., Ribeirão Preto, Brazil). The manufacturer-recommended sequence of milling cutters was observed, with the final drill having a diameter just less than that of the implant, with the aim of attaining better fixation of the screw in the substrate.

\section{Implant stability quotient analysis}

Immediately after the placement of the implants, primary stability was assessed through resonance frequency analysis using an Osstell ${ }^{\mathrm{TM}}$ Mentor (Integrations Diagnostics AB, Gothenburg, Sweden), a non-invasive, portable device that uses a transducer that is fixed to the external hex implant platform with a captive screw, at a torque of between 4 and $6 \mathrm{Ncm}$. With this device, four measurements were taken, mesial, distal, lingual and buccal, for each implant, by nearing the device's probe to the transducer without touching its topmost part. Through excitation by magnetic field pulses emitted by the device's measuring probe, resonance frequency was calculated via the response signal, the results being shown on the device, as the implant stability quotient (ISQ).

The collected data were stored in a computer and subjected to ANOVA statistical treatment and Tukey tests, at a $5 \%$ significance level for difference between the means.

\section{RESULTS}

After the statistical analysis of the values obtained from the resonance frequency analysis, it was found that, despite the fact that the implants that had undergone surface treatment showed higher values than the machined implants in all substrates (Table 1), they did not show any statistical difference between one another, with the exception of 20 PCF Nacional polyurethane (Figure 1).

Table 1. Averages and standard deviations of Master Porous and Master Screw implants inserted in pig bone, Nacional ${ }^{\circledR}$ brand polyurethane at densities of 40, 20 and 15 PCF, Synbone ${ }^{\circledR}$ brand polyurethane, and wood

\begin{tabular}{ccccccc}
\hline & Pig bone & $\begin{array}{c}\text { Nacional } \\
\text { polyurethane 40 PCF }\end{array}$ & $\begin{array}{c}\text { Nacional } \\
\text { polyurethane 20 PCF }\end{array}$ & $\begin{array}{c}\text { Nacional } \\
\text { polyurethane 15 PCF }\end{array}$ & $\begin{array}{c}\text { Synbone } \\
\text { polyurethane }\end{array}$ & Wood \\
\hline Master Porous & $69.0 \pm 10.29$ & $74.42 \pm 6.12$ & $64.34 \pm 2.00$ & $59.43 \pm 2.11$ & $61.06 \pm 2.27$ & $76.78 \pm 4.11$ \\
Master Screw & $65.43 \pm 3.80$ & $69.84 \pm 3.62$ & $54.34 \pm 6.32$ & $51.37 \pm 6.83$ & $58.06 \pm 3.73$ & $70.18 \pm 3.92$ \\
\hline
\end{tabular}




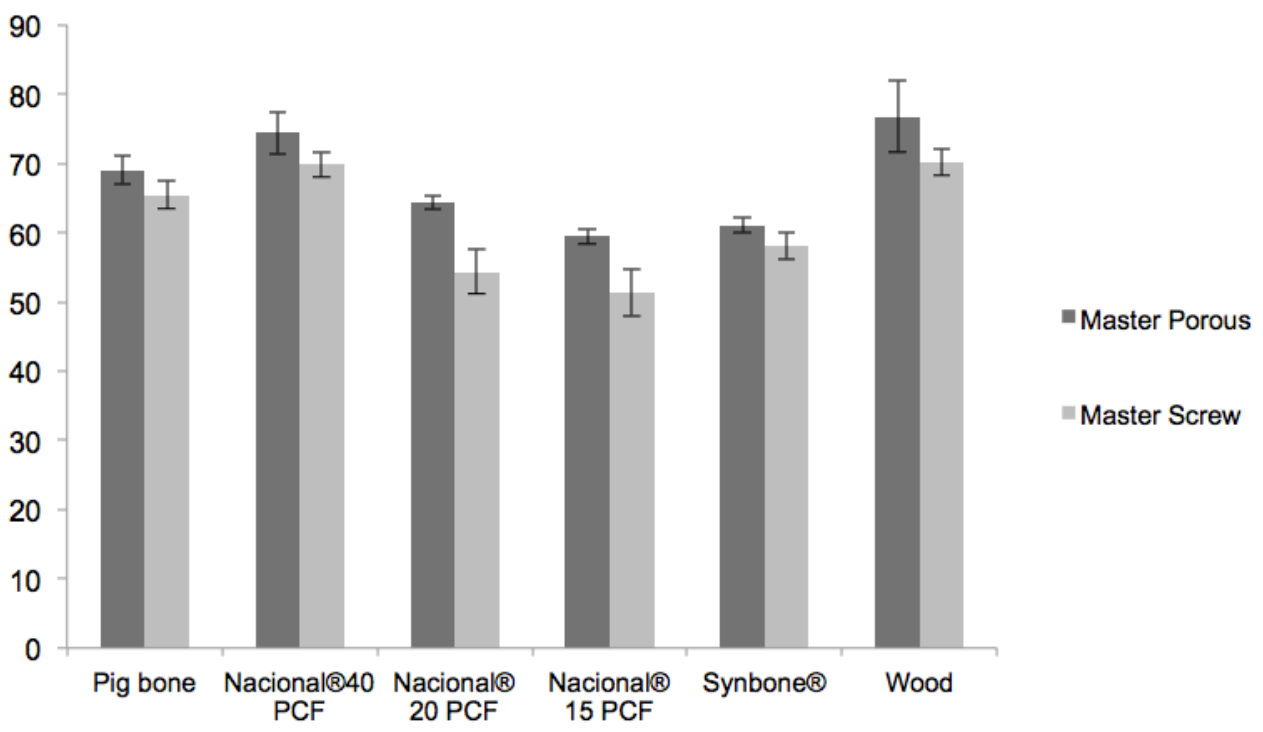

Figure 1. ISQ average and standard deviation of Master Porous and Master Screw implants in pig bone, Nacional ${ }^{\circledR}$ polyurethane at densities of 40,20 and 15 PCF, Synbone ${ }^{\circledast}$ polyurethane and wood..

The Master Porous and Master Screw implants showed the highest resonance frequency levels when inserted in the wood substrate $(76.78 \pm 4.11$ and 70.18 \pm 3.92; respectively), followed by Nacional ${ }^{\circledR}$ polyurethane at a density of 40 PCF and pig bone (Table 1). The analysis demonstrated similar behavior between the wood and the highest density polyurethane (40 PCF) substrates, regardless of whether the implant used was machined or surface treated, where no statistical difference was shown ( $P>0.05$ ) between them and also when comparing the same format of implant inserted in the two materials. Furthermore, the Master Porous implants, when inserted in pig bone, were also statistically equal to these interactions.

The lowest averages shown by the resonance frequency analysis were found in both kinds of implants when they were inserted in the lowest density polyurethane, 15 PCF, $(59.43 \pm 2.11$ for Master Porous and $51.37 \pm 6.83$ for Master Screw) (table 1). The behavior of both implants, machined and surface treated, was not statistically different in this substrate, neither in 20 PCF polyurethane nor in Synbone polyurethane $(P>0.05)$. Moreover, both Master Porous and Master Screw implants showed no statistical difference when in Synbone or pig bone.

As for the machined implants in the latter substrate, no statistical difference was found when inserted in 40 PCF polyurethane. These Master Screw implants, even in higher density polyurethane (20 PCF), were not statistically different from surface treated implants inserted in 15 PCF polyurethane (Figure 1).

\section{DISCUSSION}

Human cadaver bone is often used in laboratory tests to analyze the primary stability of implants. Due to the wide variety of specimens, a large sample is required to attain significant results, which is difficult because of factors such as availability, handling and preservation, thus leading to the search for bone substitutes for implant placements and their mechanical analysis ${ }^{22}$. In light of this, this study is concerned with using different substrates that can perform the same function as bones due to having similar characteristics and which, in addition, allow for the observation of the impact of the different densities of the materials on resonance frequency values.

In response to the attempts at finding a human bone substitute for in vitro studies, resonance frequency values of human bone, close to those of the wood and 40 PCF Nacional ${ }^{\circledR}$ polyurethane substrates observed in this study, may be cited; such as in the study by Turkylmaz et al. ${ }^{4}$, in which the average ISQ value was 73.2, similar to that found in the work of Degidi (73.5) and the studies by Aksoy $^{1}$ (72.28) and Park (76.6) ${ }^{23}$. These results, using in vivo bone, confirm the conclusions of the present research, in which the substrates that most resembled pig bone were wood and 40 PCF polyurethane, as there was no statistical difference between treated implants when inserted into either of these materials or in bone, and no statistical difference between machined implants when inserted in either 40 PCF polyurethane or in bone. 
Moreover, it is important to note that, depending on a material's density, it may show some similarity regarding the effects of the resonance frequency analysis when this density is similar to that of another substrate. The studies of Chong et al. ${ }^{9}$ show that resonance frequency readings prove to be similar when implants are inserted in higher density polyurethane (50 PCF, equivalent to D1 type bone) and average density polyurethane (40 PCF, similar to D2 type bone). This study also shows statistically similar results for polyurethane specimens with approximate densities of 20 and 15 PCF and Synbone, both in machined implants and surface treated implants.

Bone structure is a parameter for primary stability and implant success ${ }^{10}$. Many studies claim that implants inserted in the mandible have higher success rates than those inserted in the maxilla ${ }^{10-11}$ and high implant failure rates are observed when there is poor bone mineralization or limited bone resistance in terms of perceived tactile sensitivity during drilling ${ }^{3-4}$. As mechanical behavior is vital for obtaining osseointegration, several classifications have been suggested for bone quality ${ }^{5}$, however they are neither very objective nor reproducible ${ }^{4}$. Degidi et al. ${ }^{7}$ claim that a surgeon's ability to predict primary stability through subjective analysis is not always effective, mainly with low resonance frequency and insertion torque values. Therefore, more objective, systematic measurements must be encouraged, mainly in cases where an immediate loading regimen is the aim, where knowing the implant's initial stability, immediately after insertion in the bone, is of crucial importance in defining the opportune moment for the application of load ${ }^{5,7,13}$ so as to ensure natural healing and effective bone formation, thereby enabling optimal stress distribution of functional masticatory loading ${ }^{9}$.

Thus, the use of resonance frequency analysis seems to be an objective method for this purpose, as it allows the analysis of primary stability, a factor directly related to bone density. This analysis, presented as an implant stability quotient (ISQ, with a value between 0 and 100), in which a higher value indicates increased stability 2,6,13; is influenced by the bone adjacent to the implant and the rigidity of the bone-implant interface ${ }^{2-4,9,13}$. This statement corroborates this study's results, in which higher resonance frequency values were found in implants inserted in wood and 40 PCF Nacional ${ }^{\circledR}$ polyurethane, the materials with the greatest rigidity amongst those chosen as bone substitutes; it also corroborates studies that show that the resonance frequency of implants is proportional to the rigidity of the surrounding material.
Resonance frequency is compared to bone density ${ }^{11,14}$ and to other methods used to analyze primary stability, with the aim of observing proper correlation ${ }^{6,14,24}$. Studies show diminished primary stability in implants placed in low density bone tissue ${ }^{25}$ and therefore strong correlation between bone density and ISQ values ${ }^{4-5,13,25-26}$.

However, more recent studies have shown either higher levels of initial stability in implants placed in soft and dense bone ${ }^{25}$, or non-linear ratios of resonance frequency and insertion torque values or Periotest analyses with the elastic modulus of the cancellous bone ${ }^{10}$. This can be explained by the fact that primary stability, besides being closely related to bone density, also has implant design and surgical technique as influential factors ${ }^{3,8-9,27}$. Therefore, modified surgical techniques, such as the usage of drills with smaller diameters than the implant and the use of self-drilling conical implants with larger diameters, may be factors that optimize initial fixation.

Findings by Çehreli et al. ${ }^{6}$, as well as the studies by Turkyilmaz et al. ${ }^{4}$, Nkenke et al. ${ }^{14}$ and Schliephake et al. ${ }^{24}$ did not detect any correlation between resonance frequency values and bone density. The study by Turkyilmaz et al. ${ }^{4}$ detected a Spearman correlation of 0.583 , far from that detected by Degidi ${ }^{7}$ (0.247), which may be explained by the different designs studied and sample sizes. Therefore, more studies are necessary in order to compare different formats and surface treatments and their influence on the primary stability of implants.

For some authors, implant stability is more affected by bone quantity and quality than by implant design ${ }^{28}$, which can also be seen in the present study, in which lower averages of resonance frequency were found in treated and machined implants inserted in the lowest density material (15 PCF polyurethane). Generally, surface treatment did not influence primary stability, as the implants behavior upon analysis was very similar among every substrate used. This shows the influence that the type of material into which an implant is placed may have on results, being, in this study, more prevalent than the influence of the presence of surface treatment and corroborating the systematic review by Marquezan et al. ${ }^{26}$, who observed positive correlation between primary stability - assessed by several methods, including resonance frequency - and bone mineral density. This also corroborates the study by Kumar et al. ${ }^{11}$ who found that, in ex vivo bone samples with lower values of ultrasound transmission speed, a method used to assess bone quality, lower primary stability values were observed. 
A recent review showed that many researchers have an inadequate understanding of the influence of implants with rough surfaces on primary stability ${ }^{29}$. Sul et al. ${ }^{27}$, in their studies, found a relationship between primary stability values and the surface roughness of implants, also evident in the present work, which also shows higher values of initial stability in implants that underwent acid treatment, in comparison to the machined implants. The level of bone-implant contact also correlates with implant surface texture; studies have shown that, in poor quality bone, implants with acid-treated surfaces have better results than untreated implants, whose failure rates may be as much as five times higher ${ }^{10}$. After observing lower failure rates for the osseointegration of surface treated implants, Glauser et al. ${ }^{30}$ asserted that the modification of an implant's surface improves the success rates of implants that receive immediate loading, most likely due to the improvement in their performance in less dense bone. Chong et al. ${ }^{9}$ have noted that the implants used in their work that are not selfdrilling, show higher ISQ values than those that are, these results being explained by the presence of a less rough surface in the self-drilling region, as resonance frequency values increase with oxide thickness and micropore size, as shown by Roze et al. ${ }^{3}$. The results of this study corroborate these claims, despite the fact that the presence of implant surface treatment does not show any significant difference in relation to machined implants in all substrates, with the exception of 20 PCF polyurethane, highlighted by the results observed that machined implants, even in higher density (20

\section{REFERENCES}

1. Aksoy U, Eratalay K, Tözüm TF. The possible association among bone density values, resonance frequency measurements, tactile sense, and histomorphometric evaluations of dental implant osteotomy sites: a preliminary study. Implant Dent. 2009;18(4):316-26. doi: 10.1097/ID.0b013e31819ecc12

2. Brouwers JEIG, Lobbezoo F, Visscher CM, Wismeijer D, Naeije M. Reliability and validity of the instrumental assessment of implant stability in dry human mandibles. J Oral Rehab. 2009;36(4):27983. doi: 10.1111/j.1365-2842.2009.01944.x

3. Rozé J, Babu S, Saffarzadeh A, Gayet-Delacroix M, Hoornaert A, Layrolle P. Correlating implant stability to bone structure. Clin Oral Impl Res. 2009;20(10):1140-5. doi: 10.1111/j.16000501.2009.01745.x

4. Turkyilmaz I, Tözüm TF, Tumer C, Ozbek EN. Assessment of correlation between computerized tomography values of the bone, and maximum torque and resonance frequency values at dental implant placement. J Oral Rehabil. 2006;33(12):881-8. doi: 10.1111/j.1365-2842.2006.01692.x
PCF) polyurethane, did not show any statistical difference in relation to treated implants in 15 PCF polyurethane. The presence of surface treatment also did not influence primary stability assessed by resonance frequency, as found by Santos et al. ${ }^{31}$, who despite having found higher values for implants that underwent acid and anodized treatment, did not observe a statistical difference between these and machined implants.

\section{CONCLUSION}

We conclude that, despite innovations in implant surface features constantly being developed in order to contribute to the performance of osseointegrated implants, and our study finding that surface treatment had no influence on primary stability assessed by resonance frequency analysis, there is still little scientific knowledge about these factors.

\section{Collaborators}

NF OLISCOVICZ and AC REIS were responsible for developing and conducting the research, interpreting the results and writing the article. RJ SILVA was responsible for conducting the research and writing the article. CP LEPRI was responsible for the statistical work on the data obtained in the research and writing the article. MARCANTÔNIO JÚNIOR performed the scientific review and participated in writing the article.

5. Song YD1, Jun SH, Kwon JJ. Correlation between bone quality evaluated by cone-beam computerized tomography and implant primary stability. Int J Oral Maxillofac Implants. 2009;24(1):59-64.

6. Cehreli MC, Kökat AM, Comert A, Akkocaoğlu M, Tekdemir I, Akça K. Implant stability and bone density: assessment of correlation in fresh cadavers using conventional and osteotome implant sockets. Clin Oral Impl Res. 2009;20(10):1163-9. doi: 10.1111/j.1600-0501.2009.01758.x

7. Degidi M, Daprile G, Piattelli A. Determination of primary stability: a comparison of the surgeon's perception and objective measurements. Int J Oral Maxillofac Implants. 2010;25(3):558-61.

8. Kahraman S, Bal BT, Asar NV, Turkyilmaz I, Tözüm TF. Clinical study on the insertion torque and wireless resonance frequency analysis in the assessment of torque capacity and stability of self-tapping dental implants. J Oral Rehabil. 2009;36(10):75561. doi: 10.1111/j.1365-2842.2009.01990.x

9. Chong L, Khocht A, Suzuki JB, Gaughan J. Effect of implant design on initial stability of tapered implants. J Oral Implant. 2009:35(3):130-5. doi: 10.1563/1548-1336-35.3.130 
10. Rao PL, Gill A. Primary stability: the password of implant integration. J Dental Impl. 2012;2(2):103-9. doi: 10.4103/09746781.102223

11. Kumar VV, Sagheb K, Klein MO, Al-Nawas B, Kann PH, Kämmerer PW. Relation between bone quality values from ultrasound transmission velocity and implant stability parameters - an ex vivo study. Clin Oral Implants Res. 2012;23(8):975-80. doi: 10.1111/j.1600-0501.2011.02250.x

12. Ohta $K$, Takechi M, Minami $M$, Shigeishi $H$, Hiraoka $M$, Nishimurat $M$, et al. Influence of factors related to implant stability detected by wireless resonance frequency analysis device. J Oral Rehab. 2010;37(2):131-7. doi: 10.1111/j.13652842.2009.02032.x

13. Boronat López M, Peñarrocha Diago O, Martínez Cortissoz I, Mínguez Martínez I. Resonance frequency analysis after the placement of 133 dental implants. Med Oral Patol Oral Cir Bucal. 2006;11(3):E272-6.

14. Nkenke E, Hahn M, Weinzierl K, Radespiel-Tröger M, Neukam FW, Engelke K. Implant stability and histomorphometry: a correlation study in human cadavers using stepped cylinder implants. Clin Oral Impl Res. 2003;14(5):601-9.

15. Cristofolini L, Viceconti M, Cappello A, Toni A. Mechanical validation of whole bone composite femur models. J Biomechanics. 1996;29(4):525-35. doi:10.1016/00219290(95)00084-4

16. Buser D1, Nydegger T, Hirt HP, Cochran DL, Nolte LP. Removal torque values of titanium implants in the maxilla of miniature pigs. Int J Oral Maxillofac Implants. 1998;13(5):611-9.

17. Misch CE. Prótese sobre implantes. $2^{a}$ ed. São Paulo: Editora Santos; 2007.

18. Jankowsky IP, Chimelo JP, Cavancante A, Galina ICM, Nagamura JCS. Madeiras brasileiras. Caxias do Sul: Spectrum; 1990.

19. Tabassum A, Meijer GJ, Wolke JG, Jansen JA. Influence of surgical technique and surface roughness on the primary stability of an implant in artificial bone with different cortical thickness: a laboratory study. Clin Oral Implants Res. 2010;21(2):213-20. doi: 10.1111/j.1600-0501.2009.01823.x

20. Pfeil W, Pfeil M. Estruturas de madeira. $6^{a}$ ed. Rio de Janeiro: LTC; 2003.

21. ASTM. Standard specification for rigid polyurethane foam for use as a standard material for testing orthopaedic devices and instruments. Report n.: F1839-97.

22. Cristofolini L, Viceconti M. Mechanical validation of whole composite tibia models. J Biomechanics. 2000;33(3):279-88. doi:10.1016/S0021-9290(99)00186-4
23. Park JC, Kim HD, Kim SM, Kim MJ, Lee JH. A comparison of implant stability quotients measured using magnetic resonance frequency analysis from two directions: a prospective clinical study during the initial healing period. Clin Oral Implants Res. 2010;21(6):591-7. doi: 10.1111/j.1600-0501.2009.01868.x

24. Schliephake $H$, Sewing A, Aref A. Resonance frequency measurements of implant stability in the dog mandible: experimental comparison with histomorphometric data. Int J Oral Maxillofac Surg. 2006/35(10):941-6. doi:10.1016/j. ijom.2006.05.002

25. Friberg B, Sennerby L, Gröndahl K, Bergström C, Bäck T, Lekholm $U$. On cutting torque measurement during implant placement: a 3-year clinical prospective study. Clin Implant Dent Relat Res. 1999; 1(2):75-83.

26. Marquezan M, Osório A, Sant'Anna E, Souza MM, Maia L. Does bone mineral density influence the primary stability of dental implants? A systematic review. Clin Oral Implants Res. 2012;23(7):767-74. doi: 10.1111/j.1600-0501.2011.02228.x

27. Sul YT, Jönsson J, Yoon GS, Johansson C. Resonance frequency measurements in vivo and related surface properties of magnesium-incorporated, micropatterned and magnesiumincorporated TiUnites, Osseotites, SLA and TiOblast implants. Clin Oral Implants Res. 2009;20(10):1146-55. doi: 10.1111/j.16000501.2009.01767.x

28. Bischof M, Nedir R, Szmukler-Moncler S, Bernard JP, Samson J. Implant stability measurement of delayed and immediately loaded implants during healing. Clin Oral Implants Res. 2004;15(5):529-39. doi: 10.1111/j.1600-0501.2004.01042.x

29. Sennerby L, Meredith N. Implant stability measurements using resonance frequency analysis: biological and biomechanical aspects and clinical implications. Periodontology 2000. 2008;47(1):51-66. doi: 10.1111/j.1600-0757.2008.00267.x

30. Glauser R, Lundgren AK, Gottlow J, Sennerby L, Portmann M, Ruhstaller $\mathrm{P}$, et al. Immediate occlusal loading of Branemark TiUnite $^{\mathrm{TM}}$ Implants placed predominantly in soft bone: 1-year results of a prospective clinical study. Clin Implant Dent Rel Res. 2003;5(suppl 1):47-56.

31. Dos Santos MV, Elias CN, Cavalcanti Lima JH. The effects of superficial roughness and design on the primary stability of dental implants. Clin Implant Dent Relat Res. 2011;13(3):21523. doi: 10.1111/j.1708-8208.2009.00202.x

Received on: 15/3/2013

Final version resubmitted on: 15/7/2014 Approved on: 10/18/2014 
